\title{
Does Employee Ownership Increase Innovation?
}

\author{
Robert P. Garrett
}

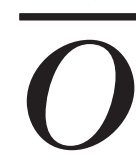
ne way that firms attempt to innovate is through investment in RED activity. However, there is much beterogeneity in innovations among firms making comparable RED investments. This article explores employee ownership's moderating effect on the relationship between RED intensity and innovative output. The basis for the moderation is that ownership increases motivation and commitment to the innovation agenda of the compa$n y$, and retains employees' entrepreneurial efforts for internal opportunities. Using bierarchical regression, the data support the bypothesis that employee stock ownership positively moderates the relationship between RED intensity and innovative output. Implications for future research and practice are addressed.

Keywords: innovation, employee ownership, corporate entrepreneurship

Innovation is the primary instrument of competition for many firms (Baumol, 2002), and is of central importance to entrepreneurship (Covin and Miles, 1999). Zaltman, Duncan, and Holbeck (1973) defined innovation as "an idea, practice, or material artifact perceived as new by the relevant unit of adoption," and in the context of corporate entrepreneurship, or "intrapreneurship" (Pinchot, 1985), the relevant unit of adoption is the corporation. Schumpeter (1934) places the entrepreneur at the center of "creative destruction," a process wherein radical innovation changes industrial dynamics. Modern researchers continue to accept Schumpeter's identification of entrepreneurship with innovation (Stopford and Baden-Fuller, 1994). Indeed, innovativeness has become widely accepted as a primary characteristic of a firm's "entrepreneurial posture" (Covin and Slevin, 1986; 1991).

Corporate entrepreneurship is an important subfield in entrepreneurship (Schildt, Maula, and Keil, 2005). It is increasingly recognized that entrepreneurial activities are not exclusively the domain of small firms and start-ups, but that larger, more established corporations can also be entrepreneurial (Ahuja and Lampert, 2001). The entrepreneurial activities of corporations have variously been referred to as corporate entrepreneurship (Burgelman, 1983; Zahra, 1993), corporate venturing (Biggadike, 1979), intrapreneuring
(Pinchot, 1985), internal corporate entrepreneurship (Jones and Butler, 1992), internal entrepreneurship (Schollhammer, 1982; Vesper, 1984), strategic renewal (Guth and Ginsberg, 1990), and venturing (Hornsby et al., 1993). While each of these manifestations of corporate entrepreneurship have their differences (e.g., corporate ventures result in the establishment of new organizational units for the firm, while strategic renewal does not [Sharma and Chrisman, 1999]), the common element among them all is innovation (Sharma and Chrisman, 1999).

A firm's ability to innovate is becoming increasingly important. Two factors causing this increase in importance are the technological revolution and greater competition in international markets (Lei, Hitt, and Bettis, 1996). Rapid change is part of the new competitive landscape, and many firms are turning to innovation for new value creation (Bettis and Hitt, 1995; Lei et al., 1996). Even in more stable environments, firms use innovation as a way to increase stagnant returns, frequently at the expense of less innovative firms (Utterback, 1994).

One way that firms attempt to innovate is through investment in R\&D activity. Greve (2003: 687) asserts that R\&D is "the organizational process most directly involved with innovations." By directing resources to R\&D activities, firms are attempting to produce new products or processes that will create or enhance a firm's competitive advantage. However, this attempt at innovating is not analogous with the actual production of innovation, and there still remains much heterogeneity in the number of innovations produced by similar firms with comparable R\&D expenditures. Recent scholarly work examines this heterogeneity by examining moderators on the relationship between $R \& D$ activity and innovation such as firm financing structures (Czarnitzki and Kraft, 2009), external markets (Tishler and Milstein, 2009), and internal capabilities and external partnerships ( $\mathrm{Su}$, Tsang, and Peng, 2009). However, there is a paucity of research investigating employee ownership plans as a determinant of innovation.

The extant research on employee ownership predominantly focuses on corporate control mechanisms (e.g., French, 1987), firm performance (e.g., Trebucq, 2004), and monitoring by outside blockholders (e.g., Park and Song, 1995). While these are important outcomes for firms, and are frequently 
studied by scholars in the field of strategic management, more conceptually proximate variables to employee ownership regarding entrepreneurship and innovation are left underexplored in the "black box" or previous research on the topic. Indeed, the work of Gamble (2000) looks inside the black box to explore managerial commitment to innovation dependent on Employee Stock Option Plan (ESOP) concentration, and Long (1980) investigates how job attitudes change under employee ownership, but any link between employee ownership and increases in innovation has been left unexplored. Such a link, if it exists, would be conceptually interesting to researchers investigating HRM systems and corporate entrepreneurship as well as practically interesting to firm managers seeking to maximize their R\&D investments.

This article explores employee ownership as a moderator of the relationship between $R \& D$ expenses and innovativeness in an attempt to explain some of the aforementioned heterogeneity. Employee ownership, measured by profit sharing and ESOPs, has been investigated by researchers considering how to create an "entrepreneurial spirit" within a company (Denton, 1993). This "spirit" is a sense that employees are working for themselves instead of for somebody else. When employees feel they have a stake in the business, they are more likely to have an entrepreneurial spirit and the sense that they can directly affect the success of the business (Denton, 1993).

Thus, firms use employee ownership as one mechanism to increase employee commitment to the firm. To the extent that employees become owners of the company, and their own personal financial performance becomes tied to the financial performance of the company, they become more committed to being productive workers within the company. Previous research has identified individual-level commitment as an important factor in R\&D effectiveness (van der Bij, Song, and Weggeman, 2003). As individual commitment increases, R\&D effectiveness also increases.

Additionally, this article proposes that stock ownership also serves as a substitute for the potentially large gains that may come from independent entrepreneurial ventures. Often, the best employees within a firm recognize opportunities outside the firm to which they may be attracted, and may desire to leave the firm to pursue those opportunities. While risky, those opportunities have large potential payoffs. The underlying supposition of this article is that firms use stock ownership as a substitute for entrepreneurial rewards: by holding ownership in the company, employees are rewarded financially for their hard work inside the firm. They are then less likely to engage in external entrepreneurial activities, and more likely to keep their innovative energies directed within the firm.

There has been much previous work examining the direct effect of employee stock ownership on firm performance
(Park and Song, 1995; Trebucq, 2004), but there is a paucity of research exploring the relationship of employee stock ownership with the more proximal concept of innovation. Many of the studies on employee stock ownership focus on ESOPs (employee stock ownership plans) as entrenchment tools that management uses to prevent acquisition. Park and Song (1995) were able to show positive effects of ESOPs on longterm firm performance when the ESOP functioned efficiently as a monitoring mechanism against managerial entrenchment. The current article is an effort to shorten the causal chain by studying a variable more proximal to employee stock ownership, namely innovation. While it is clear from earlier studies that employee stock ownership does affect firm performance, it is unclear how it affects firm performance. This research attempts to show that employee stock ownership moderates the relationship between R\&D intensity and number of innovations, and offers arguments of how and why this moderating effect operates. Since previous research has found a link between innovation and firm performance (Franko, 1989; Porter, 1990), I believe that by demonstrating the moderation of employee ownership on innovation, this research provides a bit more insight into the relationship between employee ownership and firm performance.

This article proceeds as follows. First, I develop arguments and propose hypotheses regarding the relationship between R\&D intensity and innovation, and the role of employee ownership as a moderator in this relationship. Then, I discuss the methods of how these hypotheses were investigated. This is followed by a presentation of the results, and finally I discuss the conclusions of this study along with implications for future research and practical application.

\section{Using Employee Ownership to Explain Innovation Differences RED Intensity and Innovation Production}

R\&D expenditures have long been recognized as an input firms use to develop new and valuable technology resources (Dierickz and Cool, 1989; Grabowski and Vernon, 1990). In order to develop these technology resources, firms are often required to make sustained investments is R\&D (Vassolo, Anand, and Folta, 2004; Ethiraj et al., 2005). Over time, firms with greater investments in R\&D should be able to accumulate more valuable technology resources, creating the means by which further innovations can be produced. Knowledgebased resources typically develop in a path-dependent manner (Kogut and Zander, 1992), so investments made consistently over time contribute to the development of firm capabilities (Berry and Taggart, 1994; Helfat and Peteraf, 2003), such as the innovative capability of the firm. R\&D expenses contribute to the development of technology resources within a firm, and these technology resources are used toward the 
production of innovative outcomes within the firm. Thus framed, the argument made here is not for direct correlation between R\&D expenses and innovations. The argument recognizes that firms do not have equal capabilities (Helfat and Peteraf, 2003), but that R\&D expenditures can contribute to building innovation capabilities, and that a main effect between R\&D expenses and innovations, though not perfectly correlated, will exist.

\section{Hypothesis 1: The size of a firm's financial investment} in $R \& D$ is positively related to the number of innovations produced within that firm.

As earlier discussed, similar hypotheses have been previously explored and supported, but this hypothesis is essential to the development of the rest of this article, and so it is included here. Employee ownership is next explored as a moderator of the relationship between R\&D intensity and innovation.

\section{The Moderating Effect of Employee Ownersbip}

There are a variety of ways in which a company can create ownership among its employees. Among these are cooperatives where the firm is wholly owned by its employees, and Employee Stock Ownership Plans (ESOPs), which are qualified retirement plans that award a fraction of firm ownership to its employees, giving them residual claims and voting rights (Park and Song, 1995). In addition to these more visible methods of employee ownership where the plan deals solely in the stock of the company, there are also more diversified plans where the contributions of the employee and the company may be directed to company stock among many other diversified choices (e.g., 401-k's, company savings plans, stock bonus plans).

Employee ownership can significantly affect the relationship between employees and the organization in which they work (Frolich et al., 1998). Long (1980: 727) suggested that "employee ownership operates by first affecting organizational identification, viewed as three interrelated phenomena (Patchen, 1970; Rotondi, 1975): (a) feelings of shared characteristics and common goals, (b) feelings of "belongingness" or solidarity with the organization, and (c) support of the organization or loyalty." The third of these phenomena is labeled "commitment," and is "expected to lead to various behaviors supporting the organization, such as decreased turnover, absenteeism, and grievances, increased willingness to innovate, and the like" (Long, 1980: 727, italics added for emphasis). From a financial perspective, employee ownership provides very real financial consequences to the employees. Under circumstances of organizational decline or failure, the employee owner is put in a position of risk, but the survival and growth of the firm provide valuable financial outcomes (Pierce, Rubenfeld, and Morgan, 1991).These gains and losses have an influence on the employees' commitment to the organization by motivating them to do what they can to ensure the financial success of the firm. From a psychological perspective, employee owners, as "dual" stakeholders, should experience increased intrinsic involvement in their task due to a greater sense of ownership (Paul, Ebadi, and Dilts, 1987; Pierce et al., 1991). They are also more likely to identify with, and develop a sense of belonging for, the organization (Pierce et al., 1991). Finally, employee owners are more likely to have positive interactions with coworkers, assist coworkers, and function more effectively as a team because they collectively own and control the organization (Frolich et al., 1998). This willingness to innovate, as it develops, is not to be confused with the ability to innovate. Willingness to innovate may result in more innovation attempts, but only when used in conjunction with innovation capabilities may it result in actual innovative outputs.

In addition to increased commitment, employee ownership may contribute to increased intrapreneuring (Pinchot, 1985) as a substitution for individual entrepreneurship. Employees are becoming more knowledgeable, more educated, and more demanding of their work environment. For the most part, these traits are very desirable in a firm's employees, but at the same time, employees are also becoming less loyal, more mobile, and more willing to change jobs or start their own companies. For these highly capable employees, there is certainly risk in undertaking an entrepreneurial endeavor, but the pay-off is potentially unbounded. Firms use employee stock ownership to compete with these entrepreneurial impulses of its employees. By making employees owners, the company is building a reward system for efforts that benefit the firm instead of the individual.Additionally, as owners, employees perceive that they are working for themselves rather than for someone else, so they begin to feel that they have more control over their lives and the benefits they will receive for their hard work (Frolich et al., 1998). Thus, the company is able to retain the most innovative people who might otherwise be tempted to leave the firm.

Finally, employee ownership also serves as an alignment mechanism. Employees who control large blocks of stock may be more likely than other stockholders to influence management for improved long-term financial performance (French, 1987). They are in a better position than others to monitor managerial decisions because of their proximity to management and their familiarity with company operations (Gamble, 2000). Perhaps most important in the context of innovation, they have an enhanced incentive to monitor the performance of coworkers (Bowles and Gintis, 1993). Such monitoring is expected to reduce wasteful R\&D spending. For all these reasons, the following hypothesis is presented: 
Hypothesis 2: Employee ownership positively moderates the effect of R\&D intensity on the number of innovations produced.

\section{Testing the Hypothesis \\ Sample}

The sample for this study is publicly traded, high-technology firms. High-technology firms were chosen because of the relevance of both innovation and employee ownership. First, high-tech firms are very likely involved in producing innovations because their industry demands it in order to be competitive, profitable, or even to survive (Burgelman and Valikangas, 2005). Second, many high-tech firms are beginning to use stock ownership plans as part of their compensation package (Pugh, Jahera, and Oswald, 2005).

A list of high-tech industries is published at the AeA website (http://www.aeanet.org/Publications/IDMK_definition. asp). AeA's definition of high-tech industries includes hightech manufacturing (SIC codes 357, 365, 366, 367, 381, 382, 384, and 386) and high-tech services (SIC codes 481, 482, 484,489 , and 737). COMPUSTAT was used to identify all firms operating in high-technology manufacturing industries from 1999-2004. The search was further restricted to companies having more than 500 employees during the time frame selected. By selecting only firms with 500 or more employees, it was hoped that predictable (small) size-related biases on the research variables might be avoided (e.g., smaller firms often innovate as a niche-seeking activity to an extent greater than larger firms [Fiegenbaum and Karnani, 1991]). Additionally, mid-sized and larger firms were targeted for research because prior evidence (e.g., von Hippel, 1977; Klavans, Shanley, and Evans, 1985; Thornhill and Amit, 2001) suggests that corporate innovation tends to be more pervasive among firms with more substantial resource bases. A total of 263 companies were identified in COMPUSTAT that matched the criteria for industry, time frame, and employees.

Data were collected on employee stock ownership, innovation output, and firm financial information. Availability of these data further limited the sample because not all firms participate in employee ownership programs, or they do not report their participation. The 11-k filing with the SEC is the document used to report on employee ownership plans, and these reports include information on all plans (ESOPS, company savings plans, stock bonus plans, etc.) offered by the company, as well as all investments made by the plans. However, because it is impossible to distinguish between companies not participating in ownership plans and companies that do participate but do not report it (for example, Apple Computers reports an employee stock ownership participation on their company website, but their 11-k was not available publicly), the hypotheses were tested only within the group of companies for which the 11-k was available.

\section{Measures}

Dependent variable. Innovative output was measured using patent counts for each company in the sample. This information is available at the website of the U.S. Patent and Trademark Office (www.uspto.gov). Patents represent the discovery of a product or process perceived as new by the organization. There are potential limitations of using patent data; namely, that it does not address the importance or radicalism of the innovation. However, a longlasting precedent has been established in the literature for using patent information (Lei et al., 1996) as a proxy for innovation.

Because the patent approval process can often take a significant amount of time (as much as three years), and because employee ownership in one year is unlikely to produce patented innovations in the same year (due to the pathdependent nature of innovations), employee stock ownership data was gathered for the year 1999, and patent data was gathered from 2003.

Independent variable. $R \& D$ intensity is measured by $R \& D$ expenses as a percentage of sales according to Coff (2003). The firm financial information-R\&D expenses and sales in 1999-was obtained from COMPUSTAT. The variable of R\&D intensity was lagged back to 1999 because of the anticipated delay between investment in R\&D and the actual award of a patent. Because R\&D investments lead to stocks of knowledge that are built up over time, and because the patent award process can take two or three years from the date of patent application, a four-year lag (1999-2003) seemed appropriate. As a test, additional data on the independent variable was gathered for the years 1997, 1998, 2000, and 2001. The results, discussed later in this article, were robust across lags of varying lengths of time, though the six-year lag yielded reduced significance of the results. The three-year average from 1998-2000 was also used as a check (Krishnan, Tadepalli, and Park, 2009), and the results were also robust.

Moderator variable. Information on employee stock ownership is available in 11-k filings with the SEC. The variable used from this information was company stock held per employee.

Control variables. Control variables were chosen based on their anticipated effects on both the independent and dependent variables. By controlling for these effects, the likelihood that there exist alternative explanations for the variation in innovative output was minimized. All of the following control variables were measured contemporaneously with stock ownership in the year 1999: size measured by number of employees, age, industry, total assets, and sales.

\section{Analysis}

Of the 263 companies in the sample, data on employee stock ownership was available for 77 (29.3\%). On average, the firms in the sample had 140 patents in 2003, 18,000 employees, 
sales of $\$ 4.5 \mathrm{~B}, \mathrm{R} \& \mathrm{D}$ expenses of $\$ 390 \mathrm{M}$, and total employee savings plan holdings of $\$ 930 \mathrm{M}$ in 1999 . ANOVA tests were conducted to determine if the companies reporting employee stock holdings in 11-k forms were different from the ones that did not file $11-\mathrm{k}$ forms in the sample. There was no significant difference between the companies on R\&D as a percentage of total sales. However, the companies were significantly different on number of employees and age, with the companies providing 11-k filings being larger and older on average than companies that did not file an 11-k.

To test the hypotheses, hierarchical regression analysis was employed. The raw variables gathered, however, were not normally distributed, and therefore were not immediately suitable for use in regression analysis without first transforming them. When variables possess unequal error variances and nonnormality of the error terms, a transformation may be applied to allow a model with an otherwise complex, curvilinear response function to be expressed as a simple linear regression model (Kutner, Nachtsheim, and Neter, 2004). Patents, employees, assets, sales, R\&D as a percentage of sales, and stock ownership per employee were all transformed using the natural logarithm-one of the transformations recommended by Kutner et al. (2004) — which resulted in a normal distribution for all these variables. Following the guidelines of Aiken and West (1991), the interaction terms were created by mean-centering the original variables and then calculating the interaction term in order to deal with potential problems of colinearity. The VIFs (variance inflation factors) after meancentering were no greater than 1.4 , which is well within the standards of acceptability; a maximum VIF under 10 is an indication that multicollinearity is likely not unduly influencing the least squares estimates (Kutner et al., 2004).

\section{Results}

The means, standard deviations, and correlations for the research variables are shown in Table 1 . The largest correla- tions are between the control variables representing employees, assets, and sales. This is to be expected because they are all, in fact, related to firm size. However, for the purposes of this study, they are each controlling for separate effects. Even if they do all correlate to firm size, this at least represents a very conservative approach to the regression. Other than these three variables, there do not appear to be additional correlations that raise the concern of multicolinearity.

Table 2 shows the results of the hierarchical regression analysis. As part of these regressions, multicolinearity was checked, the residuals were analyzed, variance inflation factors were determined, and the Durbin-Watson test for autocorrelation was run $(\mathrm{D}=.672$, n.s.). The procedure used for running these tests is according to Kutner et al. (2004). After transforming the number of patents by the natural logarithm, the results of these tests fell well within the range of acceptability, and so the analysis does not suffer from violations of the assumptions of regression.

After the first step of including the control variables in Model 1, I added R\&D intensity to test hypothesis one (Model 2). After doing so, I found a strongly significant positive relationship with innovative output $(\mathrm{p}<.01)$. Also, the change in R2 from Model 1 to Model 2 was .041 ( $p<.01)$. The strongly significant beta for R\&D intensity, coupled with a significantly increased explanatory power of the model allows for the conclusion that hypothesis 1 is strongly supported. This is consistent with expectations based on previous studies investigating the relationship between R\&D intensity and innovation, and is evidence that sampling only firms that have stock ownership plans has not affected the basic relationship.

The moderator variable and the interaction term were then added to the regression equation in Model 3. The variable for company stock per employee was not significant, but the interaction term with R\&D intensity was $(\mathrm{p}<.05)$. The change in $\mathrm{R} 2$ for the model was marginally significant $(\mathrm{p}<.1)$.

\begin{tabular}{|c|c|c|c|c|c|c|c|c|}
\hline Variable & Mean & Std. Dev. & 1 & 2 & 3 & 4 & 5 & 6 \\
\hline 1. Log patent & 3.26 & 2.11 & & & & & & \\
\hline 2.Age & 25.13 & 12.45 & .16 & & & & & \\
\hline 3. Log employ & 1.99 & 1.44 & $.72^{* *}$ & $.23^{*}$ & & & & \\
\hline 4. Log assets & 7.22 & 1.68 & $.78^{* * *}$ & .18 & $.93^{*}$ & & & \\
\hline 5. Log sales & 7.23 & 1.59 & $.78^{* *}$ & .17 & $.95^{* * *}$ & $.95^{* *}$ & & \\
\hline 6. Log RD/sales & -2.63 & 2.40 & $.30^{* * * *}$ & -.02 & -.01 & .14 & .05 & \\
\hline 7. Log stock/emp & 7.56 & 0.79 & $.38^{* *}$ & .15 & $.31^{*}$ & $.40^{* *}$ & .33 & .20 \\
\hline
\end{tabular}




\begin{tabular}{|c|c|c|c|}
\hline \multicolumn{4}{|c|}{ Table 2. Regression Results } \\
\hline \multicolumn{4}{|c|}{ Dependent Variable: Log of Patents } \\
\hline & Model 1 & Model 2 & Model 3 \\
\hline \multicolumn{4}{|l|}{ Step 1: Controls } \\
\hline Industry dummy 1 & .030 & .015 & .035 \\
\hline Industry dummy 2 & .067 & .032 & .005 \\
\hline Age & .067 & .057 & .062 \\
\hline Log employees & $-.435^{\dagger}$ & -.218 & -.337 \\
\hline Log assets & $.495^{*}$ & .223 & .081 \\
\hline Log sales & $.707^{*}$ & $.753^{*}$ & $.987^{* * *}$ \\
\hline \multicolumn{4}{|l|}{ Step 2: Independent } \\
\hline Log RD/Sales & & $.223^{* *}$ & $.214^{* * *}$ \\
\hline \multicolumn{4}{|l|}{ Step 3: Moderator } \\
\hline Log stock/employee & & & .075 \\
\hline \multicolumn{4}{|l|}{ Step 4: Interaction term } \\
\hline Stock/employee x RD/sales & & & $.151^{*}$ \\
\hline Model $R^{2}$ & .643 & .684 & .706 \\
\hline Adjusted $R^{2}$ & .613 & .652 & .666 \\
\hline Model $F$ & $21.036^{* * * *}$ & $21.345^{* * * *}$ & $17.847^{* * * *}$ \\
\hline
\end{tabular}

${ }^{\mathrm{a} S t a n d a r d i z e d ~ r e g r e s s i o n ~ c o e f f i c i e n t s ~ a r e ~ r e p o r t e d . ~}$

${ }^{\dagger} \mathrm{p}<.10$

${ }^{*} \mathrm{p}<.05$

$* * \mathrm{p}<.01$

$* * * \mathrm{p}<.001$

Overall, hypothesis 2 is supported by the data. Figure 1 presents a graphical representation of what this relationship looks like in the data.

\section{Conclusions}

The reality of the current competitive environment dictates that firms must innovate, but they must also make efficient investments with their resources. $R \& D$ expenditures are a traditional tool that companies use in the hope of developing innovation, but this article demonstrates that innovating is not solely a function of investing in R\&D. In order to become and remain competitive, companies must innovate and find ways to use their resources to their maximum potential. One way they can do this is by making sure the employees are motivated and committed to the organization. This research shows support for the argument that they become motivated and committed to the extent that they participate as owners in the company.

This study contributes to the existing literature on innovation by testing a moderator on the relationship between R\&D and innovative outputs. Few moderators on this main-effect relationship have been explored, and future researchers may wish to consider additional potential moderators. Such

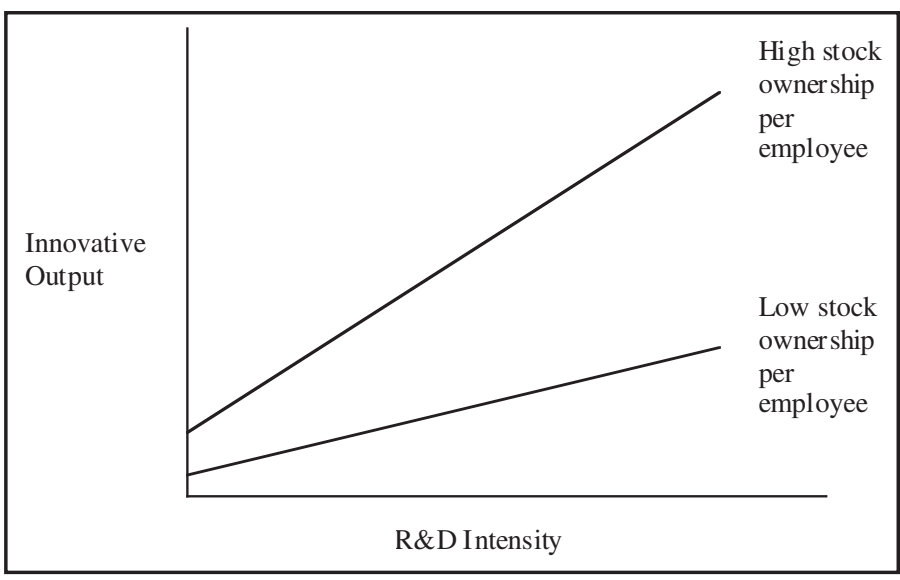

Figure 1. Employee ownership as moderator of the relationship between $R \& D$ intensity and innovative output

efforts would result in important practical implications for firms because it would allow them to make better use of their R\&D expenditures.

This study also makes a contribution to the employee stock ownership literature. Many studies have found a link between employee ownership and firm financial performance (Long, 1980; Park and Song, 1995; Trebucq, 2004), but this is the first study that explores it as a determinant of innovative output. This research attempts to show that, by affecting the employees' motivation and commitment, employee ownership can advance the innovation agenda of the firm by acting as a moderator of the relationship between $R \& D$ intensity and innovative output. By producing more innovations, firms are able to create and maintain competitive advantages that ultimately have a positive impact on firm financial performance.

The results of this study also have some important managerial implications. Managers infrequently have limitless resources and money they can invest in R\&D with the hope that they will somehow produce innovations. Instead, managers have to determine how to get the most out of their limited investment. One way to increase this input-output efficiency is to create mechanisms that motivate and commit the employees to their organization. One way to create this motivation and commitment is through company ownership.

Several limitations to this study should be considered. First, although a growing number of studies argue that the more patents a firm possesses the more intensive the firm's innovative activities may be (Patel and Pavitt, 1987; Frame and Narin, 1990: Acs, Anselin, and Varga, 2002), the use of patent data in research does not fully capture other ways in which a firm may behave innovatively. For example, while Kuratko, Covin, and Garrett (2009) tie internal corporate venturing - the creation of new business units-to a strategy of innovation, internal corporate venturing does not necessarily 
presuppose that patents will be among the outcomes of the venture(s). However, using patent counts has a clear, intuitive appeal as a measure of a firm's innovations outputs (Chin et al., 2009). Future researchers may consider gathering primary data from the firms themselves to address a more complete portfolio of innovation within the firm.

Additionally, about 70 percent of the sample was eliminated because those firms did not report 11-k filings to the SEC. From their own web pages, it is apparent that some of those firms do, in fact, have employee stock and savings plans, but this information is not available through public SEC data. This imposes the additional limitation of whether the sample is representative and unbiased. Although a statistical analysis determined that the firms filing 11-k's were no different from those that did not file, future research might improve upon this limitation by collecting primary data on employee stock ownership from each firm in the sample. Additionally, future research should consider alternative forms of employee incentive programs; this could leave to ANOVA testing to compare which incentive programs lead to the highest levels of innovation within a firm.

Finally, due to the secondary nature of the data used in this study, there was no empirical test of the path assumed by the study; namely, that a firm's use of an ESOP generates employee innovative behavior, and then that those behaviors generate innovative outcomes for the firm. Indeed, innovation capabilities of the firm are likely to moderate the latter direct effect in such a path. Future research may consider gathering primary data on these important constructs to validate this path. Such a path, though beyond the scope of the current study, would be important to future research directions on this topic.

The intersection of the literatures of innovation and employee stock ownership appears to be a promising area of research. This article is one of the first within that intersection, and future research should be encouraged to explore it further. It has the advantages of causal proximity within its variables, strong theories available, and important managerial implications.

\section{References}

Acs, Z. J., Anselin, L., and Varga, A. (2002). Patents and innovation counts as measures of regional production of new knowledge. Research Policy, 31(7): 1069-1085.

Ahuja, G., and Lampert, C. M. (2001). Entrepreneurship in the large corporation:A longitudinal study of how established firms create breakthrough innovations. Strategic Management Journal, 22(6): 521-534.

Aiken, L. S., and West, S. G. (1991). Multiple regression: Testing and interpreting interactions. Newbury Park, CA, Sage.

Baumol, W. J. (2002). The free-market innovation machine. Princeton, NJ: Princeton University Press.

Berry, M., and Taggart, J. (1994). Managing technology and innovation:A review. RED Management, 24: $341-353$.

Bettis, R.A. and Hitt, M.A. (1995). The new competitive landscape. Strategic Management Journal, 16: 7-19.

Biggadike, R. (1979). The risky business of diversification. Harvard Business Review, 57(3): 103-111.

Bowles, S., and Gintis, H. (1993). Agency theory and the democratic firm, in Bowles, S., Gintis, H., and Gustaffson, B. Markets and Democracy, Cambridge: Cambridge University Press.

Burgelman, R.A. (1983). Corporate entrepreneurship and strategic management: Insights from a process study. Management Science, 29: 1349-1364.

Burgelman, R.A., and Valikangas, L. (2005). Managing internal corporate venturing cycles. MIT Sloan Management Review, 46(4): 26-34.

Chin. C.L., Chen, Y.J., Kleinman, G., and Lee, P. (2009). Corporate ownership structure and innovation: Evidence from Taiwan's electronics industry.Journal of Accounting, Auditing E Finance, 24(1): 145-175.

Coff, R. (2003). Bidding wars over R\&D intensive firms: Knowledge, opportunism, and the market for corporate control. Academy of Management Journal, 46: 74-85.

Covin, J. G., and Miles, M. P. (1999). Corporate entrepreneurship and the pursuit of competitive advantage. Entrepreneurship Theory and Practice, 23(3): 47-63.

Covin, J.G., and Slevin, D. P. (1986). The development and testing of an organizational-level entrepreneurship scale, in Ronstadt R., Hornaday, J., Peterson, R. and Vesper, K.H. (eds.), Frontiers of Entrepreneurship Research, Babson College, Wellesley, MA, pp. 628-39.

Covin. J. G., and Slevin, D. P. (1991). A conceptual model of entrepreneurship as firm behavior, Entrepreneurship: Theory and Practice, 16(1): 7-24. 
Czarnitzki, D., and Kraft, K. (2009). Capital control, debt financing and innovative activity.Journal of Economic Behavior and Organization, 71(2): 372-383.

Denton, D.K. (1993). Entrepreneurial spirit, Business Horizons, 36(3): 79-84.

Dierickz, I., and Cool, K. (1989). Asset stock accumulation and sustainability of competitive advantage. Management Science 35(12): 1504-1511.

Ethiraj, S., Kale, P., Krishnan, N., and Singh, J. (2005). Where do capabilities come from and how do they matter? A study in the software services industry. Strategic Management Journal, 26: 25-45.

Fiegenbaum,A., and Karnani,A. (1991). Output flexibility-A competitive advantage for small firms. Strategic Management Journal, 12(2): 101-114.

Frame, D., and Narin, F. (1990). The United States, Japan, and the changing technological balance. Research Policy, 19: 447-455.

Franko, L. G. (1989). Global corporate competition:Who's winning, who's losing, and the R\&D factor as one reason why. Strategic Management Journal, 10: 449-474.

French, J. L. (1987). Employee perspectives on stock ownership: Financial investment or mechanism of control? Academy of Management Review, 12(3): 427-435.

Frolich, N., Godard, J., Oppenheimer, J. A., and Starke, F. A. (1998). Employee versus conventionally-owned and controlled firms: An experimental analysis. Managerial and Decision Economics, 19(4/5): 311-326.

Gamble, J. E. (2000). Management commitment to innovation and ESOP stock concentration. Journal of Business Venturing, 15: 433-447.

Grabowski, H., and Vernon, J. (1990). A new look at the risks and returns to pharmaceutical R\&D. Management Science, 36: 804-821.

Greve, H. R. (2003). A behavioral theory of R\&D expenditures and innovations: Evidence from shipbuilding. Academy of Management Journal, 46(6): 685-702.

Guth, W. D., and Ginsberg,A. (1990). Guest editors' introduction: Corporate entrepreneurship. Strategic Management Journal, 11:5-15.

Helfat, C., and Peteraf, M. (2003). The dynamic resource-based view: Capability lifecycles. Strategic Management Journal, 24: 997-1010.

Hornsby, J. S., Naffziger, D. W., Kuratko, D. F., and Montagno, R. V. (1993).An integrative model of the corporate entrepreneurship process. Entrepreneurship Theory and Practice, 17(2): 29-37.

Jones, G. R., and Butler, J. E. (1992). Managing internal corporate entrepreneurship:An agency theory perspective.Journal of Management, 18: 733-749.

Klavans, R., Shanley, M., and Evans, W. M. (1985). The management of internal corporate ventures: Entrepreneurship and innovation. Columbia Journal of World Business, 20(2): 21-27.

Kogut, B., and Zander, U. (1992). Knowledge of the firm, combinative capabilities, and the replication of technology. Organization Science, 3: 383-397.

Krishnan, H.A., Tadepalli, R., and Park, D. (2009). R\&D intensity, marketing intensity, and organizational performance. Journal of Managerial Issues, 21(2): 232-244.

Kuratko, D. F., Covin, J. G., and Garrett, R. P. (2009). Corporate venturing: Insights from actual practice. Business Horizons, 52(5).

Kutner, M. H., Nachtsheim, C. J., and Neter, J. (2004). Applied Linear Regression Models. New York, McGraw-Hill Irwin.

Lei, D., Hitt, M.A., and Bettis, R. (1996). Dynamic core competencies through meta-learning and strategic context.Journal of Management, 22(4): 549-569.

Long, R. J. (1980). Job attitudes and organizational performance under employee ownership. Academy of Management Journal, 23(4): 726-737.

Park, S., and Song, M. H. (1995). Employee stock ownership plans, firm performance, and monitoring by outside blockholders. Financial Management, 24(4): 52-65. 
Patchen, M. (1970). Participation, Achievement, and Involvement on the Job. Englewood Cliffs, NJ: Prentice Hall.

Patel, P., and Pavitt, K. (1987). Is Western Europe losing the technological race? Research Policy, 16:59-85.

Paul, R. J., Ebadi, Y. M., and Dilts, D.A. (1987). Commitment in employee owned firms: Involvement or entrapment? Quarterly Journal of Business and Economics, 26(4): 81-99.

Pierce, J. L., Rubenfeld, S.A., and Morgan, S. (1991). Employee ownership:A conceptual model of process and effects. Academy Of Management Review, 16(1): 121-144.

Pinchot III, G. 1985. Intrapreneuring. New York: Harper \& Row.

Porter, M. E. (1990). The competitve advantage of nations. New York: Free Press.

Pugh, W. N., Jahera, J. S., and Oswald, S. L. (2005). ESOP adoption and corporate performance: Does motive really matter? Journal of Business \& Economic Studies, 11(1): 76-92.

Rotondi,T. (1975). Organizational identification: Issues and implications. Organizational Performance and Human Behavior, 13:95-109.

Schildt, H.A., Maula, M., and Keil,T. (2005). Explorative and exploitative learning from external corporate ventures. Entrepreneurship Theory and Practice, 29(4): 493-515.

Schollhammer, H. (1982). Internal corporate entrepreneurship, in Kent, Sexton, and Vesper (eds.), Encyclopedia of Entrepreneurship: 209-229. Englewood Cliffs, NJ: Prentice Hall.

Schumpeter, J.A. (1934). The Theory of Economic Development. Cambridge, MA: Harvard University Press.

Sharma, P., and Chrisman, J. J. (1999). Toward a reconciliation of the definitional issues in the field of corporate entrepreneurship. Entrepreneurship Theory and Practice, 23(3): 11-27.

Stopford, J. M., and Baden-Fuller, C. (1994). Creating corporate entrepreneurship, Strategic Management Journal, 15(7): 521-536.

Su, Y. S.,Tsang, E., and Peng, M. (2009). How do internal capabilities and external partnerships affect innovativeness? Asia Pacific Journal of Management, 26(2):309-331.

Thornhill S., and Amit R. (2001).A dynamic perspective of internal fit in corporate venturing. Journal of Business Venturing, 16(1): 25-50.

Tishler, A., and Milstein, I. (2009). R\&D wars and the effects of innovation on the success and survivability of firms in oligopoly markets. International Journal of Industrial Organization, 27(4): 519-531.

Trebucq, S. (2004). The effects of ESOPS on performance and risk: Evidence from France. Corporate Ownership and Control, 1(4): 81-93.

Utterback, J. M. (1994). Mastering the Dynamics of Innovation. Boston: Harvard Business School Press.

van der Bij, H., Song, X. M., and Weggeman, M. (2003). An empirical investigation into the antecedents of knowledge dissemination at the strategic business unit level. The Journal of Product Innovation Management, 20: 163-179.

Vassolo, R., Anand, J., and Folta,T. (2004). Non-additivity in portfolios of exploration activities: A real options-based analysis of equity alliances in biotechnology. Strategic Management Journal, 25: 1045-1061.

Vesper, K. H. (1984). The faces of corporate entrepreneurship:A pilot study. In Hornaday, J.A., Tarpley, F., Jr., Timmons, J.A., and Vesper, K.H. (eds.), Frontiers of entrepreneurship research: 294-326. Wellesley, MA: Babson College.

von Hippel E. (1977). Successful and failing internal corporate ventures: an empirical analysis. Industrial Marketing Management, 6: 163-174.

Zahra, S.A. (1993). A conceptual model of entrepreneurship as firm behavior:A critique and extension. Entrepreneurship Theory and Practice, 17(4): 5-21.

Zaltman, G., Duncan, R., and Holbeck, J. (1973). Innovations and Organizations. New York:Wiley \& Sons. 


\section{About the Author}

\section{NEjE}

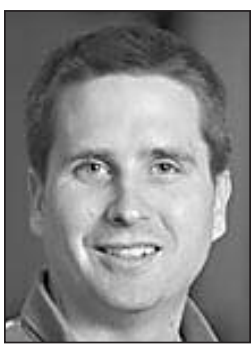

ROBERT P. GARRETT (robert.garrett@bus.oregonstate.edu) is an assistant professor of management and entrepreneurship in the College of Business at Oregon State University. He recently completed his doctoral degree at Indiana University, where his research focused on corporate entrepreneurship and internal corporate ven-

turing. His research interests continue to be concentrated in managerial practices regarding entrepreneurship within the corporate context. 